\title{
Educational Elements for Healthy Aging
}

\author{
Claus Dieter Stobäus ${ }^{1}$, Simone Stochero Kummer ${ }^{2}$, Carolina Schaan Pessano ${ }^{3}$, \\ Jordana Wruck Timm³ ${ }^{3}$ Juan José Mouriño Mosquera ${ }^{4}$
}

\author{
${ }^{1}$ Postgraduate Program in Education and in Biomedical Gerontology, Pontifical Catholic University of Rio Grande do Sul, Rio \\ Grande do Sul, Brazil \\ ${ }^{2}$ Postgraduate Program in Biomedical Gerothology, Pontifical Catholic University of Rio Grande do Sul, Rio Grande do Sul, Brazil \\ ${ }^{3}$ Postgraduate Program in Education, Pontifical Catholic University of Rio Grande do Sul, Rio Grande do Sul, Brazil \\ ${ }^{4}$ Postgraduate Programs in Education, Pro-Rectory of Postgraduate and Research, Pontifical Catholic University of Rio Grande do \\ Sul, Porto Alegre, Brazil \\ Email: stobaus@pucrs.br
}

How to cite this paper: Stobäus, C. D., Kummer, S. S., Pessano, C. S., Timm, J. W., \& Mosquera, J. J. M. (2018). Educational Elements for Healthy Aging. Creative Education, 9, 1854-1871.

https://doi.org/10.4236/ce.2018.912136

Received: August 3, 2018

Accepted: September 23, 2018

Published: September 26, 2018

Copyright $\odot 2018$ by authors and Scientific Research Publishing Inc. This work is licensed under the Creative Commons Attribution International License (CC BY 4.0).

http://creativecommons.org/licenses/by/4.0/

\begin{abstract}
The article attempts to examine aspects of aging, in a positive sense, understanding Education as an aid to preventative measures in the health-care of the elderly, leading to aspects of health and quality of life, emotional health and well-being of the elderly within the framework of Positive Psychology, and its application to educational activities for the elderly. Health is currently a highly popular topic of discourse in all media platforms. Doctors and professionals in the field, in addition to other interested public bodies, comment daily on the issues involved in this topic and, principally, there is now a concern with the planning of preventative measures, as a factor that can guarantee a better quality of life and greater longevity. In addition to the discussions between the authors within the research group Teaching and Learning in Biomedical Gerontology of PUCRS, we used elements developed in our classes in Biomedical Gerontology with our students ${ }^{1}$.
\end{abstract}

\section{Keywords}

Health Promotion, Disease Prevention, Quality of Life, Old Man, Education, Positive Psychology

\section{Introduction}

In a time when people are "overrun" by the demands of time, and the necessity

${ }^{1}$ In the writing of the article, we also relied on the help of six of our then students of the Master's and Doctoral Program in Biomedical Gerontology, Teaching and learning in Gerontology, classes II, Aline Zuardi Maia, Marta Novelo, Neusa Maria de Oliveira Chardosim, and 2016 II, Luís Carlos Elejalde de Campos, Vanessa Binotto, Larissa Lopes Branco. 
of surviving in a world that daily requires more and more (more work, more demands, more challenges and more resilience), we propose, from this work, a reflection on some minimum measures that we can adopt, thus leading to a better quality of life, in which we prioritize the care of our most precious possession, health.

In forming this paper, we chose to write from the perspective of Positive Psychology. Psychology has mainly concerned itself with questions of illness and possible problems we may encounter throughout life. Positive Psychology has as its focus human potentialities, virtues and positive emotions (Portella, 2014; Pacico \& Bastianello, 2014).

Fatigue accumulates, commitments multiply, and the result of this is a lack of time to take care of oneself and of one's health. In this context, we present a brief survey of theoretical perspectives and population data, seeking correlations to relate to health, quality of life, the balance between personal and professional life and better management of our time. These are essential topics, but seem to be in the background, we being faced with so many demands.

\section{An Aging Population in the Current Context}

The increase of an aging population has brought with it changes in the needs of the social organization in which we live. More than two decades ago, there was already reference to the changes related to the phenomenon and the process of epidemiological transition (Veras, 1991).

The theory of epidemiological transition, proposed by Omram (1971, apud Lebrão, 2007), is focused on the complex changes in health and disease patterns and on the interactions between these patterns and their determinants and consequences. These changes in standards relate to the reduction of mortality from infectious diseases and the increase in communicable diseases. It is a theory which presupposes the replacement of communicable diseases with non-communicable diseases and external causes; suggesting a shift in the burden of morbidity and mortality from younger to older individuals. Together, triggering the substitution of a predominance of mortality, with a predominance of morbidity.

As reported by Kummer (2014), the understanding of the term epidemiological transition must be analyzed as one of the constituent parts of the global understanding of health transition, which includes elements of social conceptions and behaviors, corresponding to the basic aspects of health in human populations.

Further in the search of theoretical lines to better structure our analysis, we can make reference to the biological theory, which presents aging is a gradual process of decline in structure, function, organization and differentiation, whose end point is death. Biological aging is defined as the progressive decrease in adaptive capacity and survival (Néri, 2013). However, it is important to point out that this is a normal process. 
This aging process is interfered with by the presence of diseases and disabilities dependent on the joint action of genetics, individual behavior and access to scientific, technological and social resources, which can trigger end states of severe disorganization and undifferentiation. When in optimum conditions, the influence of genetics, the environment and behavior throughout life, individuals may age well, presenting the normative changes of senescence, but with small functional losses, few and controlled chronic diseases and maintenance of activity and social participation.

Considering this positive outcome, there is then an aging process which can be considered successful and healthy, through the inclusion of health and well-being.

The trajectory of human aging has a significant variability, depending on the level of biological and psychological development reached by individuals and cohorts due to the joint action of genetics, social, economic, medical, technological and psychological resources (Néri, 2013). Looking at the approaches mentioned above, we direct the thinking for some analysis. Regarding the prevalence of chronic degenerative diseases among the elderly, it is necessary to establish and consolidate systematic healthy living habits, in order to delay the appearance of these diseases, or establish if these diseases are also eased by healthy living habits.

However, one may think that these patterns of behavior are not well established, or that the promotion of health actions do not play such an effective role, or socio-economic conditions are possibly interfering with this process, when a high frequency of hospitalizations is identified of elderly people due to causes that are related to the actions of primary health care, as can be seen in the data discussed in Kummer's (United Nations of Brazil-UN/BR, 2014) concerning cases of cardiovascular and respiratory diseases.

In order to emphasize the importance of advocating for health education, promotion and preventative actions, we can include the words of Pinto \& Bastos (2007), noting that the elderly had a mean of $6.63 \pm 2.54$ comorbidities, with values of at least three, and a maximum of 17 associated diseases. Diseases of the musculoskeletal system and/or connective tissue are cited with a $67.5 \%$ occurrence of the elderly.

Wright (2008), after a review study, found that $61.4 \%$ of the elderly needed to seek health services over a six-month period, and that $6.6 \%$ reported at least one hospital stay. Data also shows that $78.1 \%$ of the elderly have one to five associated chronic diseases, with prevalence of chronic degenerative diseases, psychiatric disorders and physical changes caused by immobility.

In this context, the present approach has taken as its starting point the theoretical lines mentioned above, since they end up giving direction to the understanding of the changes that have occurred throughout the aging process.

In better explaining the socio-economic issues mentioned above, which may also interfere in the accomplishment of healthy living habits, what is known is 
that the average per capita household income influences the individual administration of private spending, assuming consumption of education, transportation, food and medicines, among other consumer goods that may reflect on the health of the population. In parallel to the average per capita household income of a population, taxes and public collections are levied, assuming that the higher the average per capita household income, the higher the GDP and, consequently, there will be an influence on public spending, in which one can invest more in basic sanitation and health promotion, among other high level priorities. After all, there are innumerable factors that interfere with the health status of the population, and the responsibility for it belongs to the individual person, to the family and to the State, as already provided for in the Constitution of the Federative Republic of Brazil (Brasil, 1988).

In order to analyze the current context of aging of the population, it should be remembered that in 2014:

The World Health Organization ( WHO) declared that in the coming decades the world population over 60 years of age will increase from the current $841 \mathrm{mil}-$ lion to 2 billion by 2050, making chronic diseases and the welfare of the elderly new challenges for global public health (United Nations of Brazil-UN/BR, 2014).

In the Brazilian reality, based on the population estimates presented for the year 2012 by the TCU (from the IBGE demographic census of 2010), it was identified that the elderly already represented $10.77 \%$ of the total population (total population Brazil $=193,976.530$, elderly population Brazil $=20,889,849)($ Brazil, 2016).

In the State of Rio Grande do Sul, the elderly population, in the same IBGE estimate, the percentage of the elderly was 13.63 out of the total population of the State (Total population RS $=10,770,603$; Elderly population $\mathrm{RS}=1,467,957$ ) (Brazil, 2016).

In this sense, if the life expectancy of people is increasing, it is necessary to focus on actions to prevent and treat diseases that enable people to live healthier lives, seeking alternatives to prevent the risks of developing diseases. In view of the figures presented, there is a responsibility to improve the quality of life for the people, seeking to extrapolate the scope of the health sector and provoking an intersectoriality, in order to fully meet the needs of this population longevity.

When we talk about intersectoriality, it refers to the issues of social assistance, social security, accessibility to care, health education, among others. For this, strategies are needed to improve the prevention and management of chronic conditions, providing excellent care accessible to all the elderly, taking into account the physical and social environment. As is the case, "according to WHO, especially in high-income countries, where increased longevity is mainly due to the decline in deaths from cardiovascular diseases, such as stroke and ischemic heart disease, by simple and low-level cost interventions to reduce tobacco use and high blood pressure" (United Nations of Brazil-UN/BR, 2014).

Considering that health is not restricted to the treatment of diseases, but en- 
compasses a biopsychosocial well-being, including preventive and health promotion measures, it is stressed that children, adolescents, adults or the elderly, all persons in different contexts, need access to Health Education in order to better understand the environment in which they live. It is precisely this understanding that allows for the development of adequate activities, and can help the "biological" model to be gradually replaced by a biopsychosocial conception of health (Santos, Moreira, Rocha, \& Ribeiro, 2011; Barba, Martinez, \& Carrasco, 2003).

Thus, in the following section, we present greater detail with regards to the complexity of prevention, facilitated by the circumstances of health education that can be inserted throughout the human lifespan.

\section{Education as an Aid in Preventative Health of the Elderly}

Education, which is the subject of great discussions at the global level, has been progressively influencing the daily lives of people, society and governments, a fact commented on by Delors (2005), when he comments on education as the key to economic evolution, which can prevent unemployment, aid technological growth, as well as steer other issues involving the progress of society and people.

Complementing the commentary, we find that "education seems to have been perpetually in crisis in our century, at least if we take into account the insistent voices of alarm that have long warned us about it" (Savater, 1998: p. 17), a fact that deserves attention and which should serve as an alert to search for new actions, which make it possible to change this scenario.

Based on the reflections of these authors, and knowing that Education is fundamentally based on the formation of people, it is important that it be made available to all citizens, regardless of their social situation, the environment in which they live and their age .

Considering the factors and environments that are involved in this theme, the family environment is where the individual starts their training, from the personnel to those related to values, beliefs and ethical principles.

On this fact, Savater (1998: p. 69) comments that individuals “before contacting their teachers, have already widely experienced the educational influence of their family environment and social environment, which will continue to be a determining factor". So, if, on the one hand, formation begins in the family environment, how does it perpetuate itself throughout life, how does formation (or education) occur in adulthood? How do we keep learning? In what environments? In what way? With what tools?

Considering that this article deals with the issues that affect the health, welfare and quality of life of the elderly, let us look at some issues that involve the education process of this sector of the population in particular.

An extremely important factor to start this reflection stems from increasing data regarding population and life expectancy of the population, as previously noted. In addition, according to data from the Brazilian Institute of Geography and Statistics (IBGE). The life expectancy in Brazil rose in 2013 to 74.9 years of 
age for both sexes, and the mortality rate decreased, with fewer women in this category (Cardoso, 2014).

The data shows that there are also programs being implemented directed to the elderly, such as: the creation of the elderly status, benefits in purchasing more affordable medicines, among others, that allow for greater care of this portion of the population and contribute to a healthier life, from prevention to the treatment of diseases (Cardoso, 2014).

Concerning this audience and the issues that are related to them, and relating to the previous subtitle, Júlio (2009: p. 90) comments that:

Three major challenges present themselves for the near future. The first one is to retrain people into our work cycles, as well as to develop appropriate roles for these veteran armies. The second is to ensure differentiated health care for this population, such as cancer prevention, control of hypertension and diabetes. It is not enough to live longer. It is necessary to live well, which will allow the continuation of productive activity.

Two issues stand out from this quotation: the first in relation to the empowerment of people, or retraining, as the author says, and the second, differentiated health care. Regarding empowerment, it is important to comment that every person, throughout their life, continues to learn, in different ways, at different times, considering the stimuli given, the environments in which they live, the relationships they establish, how they care for their health, and many other issues that involve each individual. Every older person keeps learning.

An important contribution is that of Mosquera \& Stobäus (1983: p. 87), who refer to the third stage of adult life, when they say that:

The last sub-phase is approximately between the ages of 60 and 65, which we termed the final middle adulthood or old pre-adulthood. Here would be problems such as retirement, withdrawal from work, a phenomena for workers around the world, as well as the failure to develop a life of leisure. It is at this moment that we could really question, in a very profound way, because we only know how to do domestic or professional obligations, because we do not learn to cherish our hobbies, ambitions and dreams.

Another important contribution concerns aging itself, whose theme is treated by Mosquera \& Stobäus (2006b: p. 77) is:

[...] a period of great personal fulfillment, in which the opportunity to be involved in the exploration of options that were previously not possible due to family or employment issues is presented. The healthiest aging is a process of optimization and selective compensation. On the other hand, this process implies maximizing interpersonal and environmental support, which is why the majority of older people who have aged well have a capacity that leads them to be wiser.

In conclusion, we can say that everyone can learn and seek reassurance at any time in their life, from their childhood to their adulthood or old age, but it is up to the individual to seek the care needed to ensure a healthier life. 


\subsection{Health and Quality of Life}

According to the World Health Organization (WHO, 1946), health is considered to be the physical, psychological and social well-being of individuals. From this concept we can begin our reflection on the relationship between health and quality of life and well-being, considering the definition proposed by the W.H.O.

Quality of life, which is related to a person's life conditions, involving our physical, mental, psychological and emotional well-being, can be understood simply as satisfaction or feeling good. What quality of life means for each individual is subjective and varies enormously.

The term "quality of life" leads us to reflect how health, in its essence, taking into consideration the factors noted above and adding present day life expectancy, is related to work, family, friends, social life and the digital/virtual world.

A survey conducted by UNIMED/POA (2009) evaluated the level of well-being of the population, and aimed to establish the Well-being Index (IBE) of the population of Rio Grande do Sul-Brazil. The result showed that the overall rate of well-being of the population of Porto Alegre was $0.67 \%$, which is consistent with the average of other countries where similar research has been applied, with the exception of highly developed countries, where the rate is closer to 0.80 .

The research considered 12 factors: Relationship with Work, Eating Habits, Culture and Leisure, Autonomy and Freedom, Environment, Welfare Psychology, Spirituality, Social Coexistence, Physical Well-being, Basic Access, Government and Evaluation of Life.

In the project, the UNIMED Cooperative interviewed people on the streets of the city to find out how they were feeling, where in the rush of day-to-day living it is practically impossible to stop to think about the direction our life is taking. "At times it may seem like things are going well, but analyzing deeply, we realize that maybe there are points where we need to become more aware and improve. Is all well? Are you well?' (UNIMED/POA, 2009)

Considering the issues discussed above, another important issue to be considered for a good quality of life and well-being, is maintaining the balance between mind-body-spirit, promoting our emotional health, or spiritual, as some authors have considered in their studies.

Júlio (2009: p. 144), when speaking about spirituality, recommends that:

[...] we should pay special attention to spiritual health. It is urgent that we meditate again. And all religions offer methods for this. Prayer takes us to this refuge of the mind, in which we can revisit our actions and reconcile ourselves with the cosmos. In the application of this prophylaxis it is worth contemplating nature. The sea sweeping the beach, the bustle of seagulls. A blessed vaccine that costs nothing.

But emotional health is not only linked to emotions, sentiments and feelings, its dimension extends to other issues linked to the emotional side of people. Factors such as stress, tension, depression, anxiety, happiness, joy and pleasure are connected to the sense of physical, mental and emotional well-being. As 
Rossi (1997), stated, it is impossible to live without stress, which in the right measure, helps us to develop more. Many believe that they even perform better when in crisis situations. However, the accumulation of stress, due to frustrations and daily problems, also cause imbalance, anxiety and tension, and the physical and emotional damage may be irreversible.

In the meantime, research shows that most people present diagnoses of depression and stress, both in the business world and in their personal lives. We know that some degree of anxiety is perfectly acceptable, but for some people, anxiety becomes overwhelming and can interfere with the normal functioning of life. Depression, depending on the degree we have identified, affects our lives and the lives of those around us, affecting our most primary habits such as eating, sleeping, and socializing with others (IBGE, 2003).

So the need to take care of oneself, of one's health in every possible dimension to survive the new age, is clear. On the other hand, it is equally necessary to take care of the other, our relationships, emotions and deeper feelings, and technology cannot and should not alienate human beings from each other. Moreover, such care must be attempted in all age groups of life, but especially in adulthood.

\subsection{Positive Psychology, Emotional Health and Well-Being of the Elderly}

At the beginning of the article, in search of data and theories, we quoted the theoretical lines that helped us in the construction of this text and that would also help in the analysis of the references discussed here. These are the epidemiological transition theory, proposed by Omram (1971, apud LEBRÃO, 2007) and the biological theory of Néri (2008). Allied to them, or more than that, the 'chief' theoretical contribution, the driver of our work, is guided by the theoretical assumptions of Positive Psychology.

As briefly outlined in the introduction, Positive Psychology focuses on human potentialities and virtues. According to Snyder \& Lopez (2009), Positive Psychology has its purpose in investigating the qualities of people and in helping to promote their positive functioning. In this text, we focus on the bias of this theoretical contribution, then go through the issues related to the health and well-being of the elderly.

In order to explain the form adopted in the application of this bias to the present study, it should be clarified that, around the 1950s, we had Humanist Psychology, guided by Maslow. In 1954 the term Positive Psychology emerges for the first time in his work (Pacice \& Bastianello, 2014). The movement of Positive Psychology, with this nomenclature, began in the 1990s, starting with Martin Seligman as its main reference (Portella, 2014).

In Seligman's (2011) work, two theories appear: the theory of authentic happiness and the theory of well-being. In the first, the goal of Positive Psychology, as well as the goal of Richard Layard, is to increase the amount of happiness in people's lives and on the planet. In the second, on the other hand, the goal of 
Positive Psychology is plural and significantly different: it is to increase the amount of "flourishing" in people's lives and on the planet (Seligman, 2011: p. 37).

Here we adopt this second strand. In this sense, Seligman (2011: p. 23) says: "[...] the theme of Positive Psychology is well-being, that the main criterion for measuring well-being is flourishing, and that the goal of Positive Psychology is to increase this flourishing". Therefore, when we chose to adopt the bias of Positive Psychology for analysis and discussion in the present text, we did so from this point of view, in order to increase flourishing and, consequently, well-being in adults of this older age group.

Thus, according to Timm, Stobäus, \& Mosquera (2009: p. 234):

Well-being does not exclude malaise, it is inseparable to speak of one and not to think of the other, because they are both at the same time distinct and complementary sides of the same coin, just as more traditional Psychology focuses more on pathology/disease and Positive Psychology has a more salutogenicl health focus, in the sense of reminding us more about prevention or acting in favor of well-being.

Therefore, we take into account the most common illnesses that affect the age range of which we deal with in this text. However, our focus is on the virtues and salutogenic aspects that also involve the said age range. Thus, Timm, Stobäus, \& Mosquera (2014) also defend the importance of recognizing causes and symptoms of malaise, so that the possibilities of intervention can be increased.

Therefore, before thinking about the referral of the elderly to the psychologist/physician with the intention of reversing some emotional or mental/physical illness, we emphasize the pertinence of working for prevention, focusing on Positive Psychology, seeking to avoid the possibility of illness.

Thus, "[...] the interest in prevention and/or action in favor of well-being, is in the sense of using strategies that prevent this malaise, diminishing its symptoms" (Timm, Gomes, Stobäus, \& Mosquera, 2014: p. 30).

That is, we recognize the existence of illness and malaise and that they do not cease to exist. Our attention is focused on their prevention. Or, for a joint work, in which we can deal with pathologies, but also work with health-related aspects, aiming for an increase and recognition of well-being in the individual.

In this way, for Hué (2009), this sense of well-being is the result of the balance between possibilities and desires, between capacities and needs. It is, therefore, for the professional to work to address these questions and to assist the elderly in their search for this balance.

Linking this issue of well-being to the definition given by the W.H.O. for the term healthy, already cited in this text, as something different from simply not being sick, health becomes a state of physical, emotional, mental and social well-being, from which point, the person can "become capable of developing their potentialities, resulting in an indisputable relevant social function [...]". (Timm, Gomes, Stobäus, \& Mosquera, 2014: p. 27).

In the meantime, we understand that this full state of well-being, acts both in 
the individual and social sphere of each individual, especially in the age range that we discuss in this article.

Thus, it is important to note that, according to Seligman (2009: p. 15):

Experiences that induce positive emotions make negative emotions dissipate quickly. The strengths and virtues, as we shall see, act as a buffer against unhappiness and psychological disorders, and can be the key to resistance. The best therapists do not simply cure the symptoms, they help build strengths and virtues.

That is, it is a work that aims to highlight the strengths and virtues of each individual, to highlight the capacities that each one has in a certain age group. It is well known that, over the years, some skills are impaired, however, others may arise, and the role of the professional who works under this bias will be there in aiding this development.

Seligman (2011) already argued that Positive Psychology is able to make people happier. Therefore, we consider it pertinent for further research and use of the practice, regardless of the context of the age group, since, according to Mosquera \& Stobäus (2006a: p. 84), "every human being needs positive valuation, or positive self-esteem, in its fullest sense, and this is learned through the internalization, or introjection of the experiences of valorization carried out by others for it [...]".

With this, we perceive Positive Psychology as a powerful tool in achieving the emotional health and well-being of the elderly, if we work with them, in a preventive way, highlighting their strengths, potentialities and virtues, above all, to the individual. In relation to Positive Psychology and its focus on human strengths, it is worth noting, according to Timm, Gomes, Stobäus, \& Mosquera, (2014: p. 36), that:

This new perspective brings us hope of increasing people's well-being, regardless of the difficulties or traumas they have had in the past. All people can, at any stage of their lives, give more emphasis to and learn about their positive emotions, provided they are aware of them. Positive Psychology brings in its theoretical foundation this pivotal point, working precisely with the emotions, be they positive or negative, because they have components like feelings, sensorial aspects, aspects of reasoning and action. All emotions can be stimulated as long as, in a conscious way, the person makes that choice. They also act on the immune system, thereby helping to improve overall health, preventing aging and increasing longevity.

Therefore, working with Positive Psychology with the elderly is not only possible, it is considered fundamental and can trigger gains, both in the sense of a better quality of life and in a longer life span, elevating well-being and diminishing the instances of sickness.

\subsection{Application of Educational Activities to the Elderly}

In this section of the paper, we will consider some of the ideas developed by our 
students of the Master and Doctorate program in Biomedical Gerontology, Teaching and learning in Gerontology, class 2015 II; Aline Zuardi Maia, Marta Novelo, Neusa Maria de Oliveira Chardosim: and 2016 II; Luís Carlos Elejalde de Campos, Vanessa Binotto, Larissa Lopes Branco, as examples of possible implementations of activities with elderly people, expanded for this article.

1) Intervention by family caregivers of people with Alzheimer's disease (Aline)

As (Alzheimer's Syndrome) is a progressive neurodegenerative disease, which causes functional decline in the individual's life, these people need caregivers who are well prepared to care for them and provide them with activities such as slow changes in their routine and support in the emotional aspects of life, as well as in the life of the caregiver themselves, often being an elderly family member.

This new function requires preparation, dedication, patience and generates several feelings on the part of the caregiver, some of them negative. Thus, it also needs to be "looked at", having a space for you to deal with the subject in a more academic, and emotional way. It is essential that you also allow yourself to live with your ambivalent feelings, in order to strengthen yourself emotionally.

As proposed, activities could be:

- Individual support: the ability to invest in oneself. With this, we acquire or improve mental resources which are required in dealing with our own life situation, alongside that of the family member suffering dementia, through establishing better and sound interpersonal relationships as well as aspects of resilience and coping, as proposed by Positive Psychology.

Other aspects are also important in ensuring that the relationship between the family member and the patient does not become enmeshed and fragile, and aid the helper in maintaining their role without interfering with their own personal issues.

- Group support: this happens so that the relatives can nourish themselves, self-teaching and learning with discussions of similar situations and also of different ones. The group learns/teaches from a focused group structure, with the mediation of a coordinator with an understanding of the technique, in which the participants feel welcomed, being able to share with those who have empathy, in which they express feelings and work through them.

These are approaches which offer hospitality, a therapeutic space and affection, in which participants feel safe and willing to learn and teach new knowledge, skills and values.

In this sense, we emphasize that aspects of caring for oneself obviously requires support in maintaining physical health (such as adequate sleep/rest and feeding) through rotation with the other caregivers/relatives (Mosquera \& Stobäus, 2006b). Also coping and (re) arrangement strategies in their emotions and feelings, as well as healthy social relationships (such as the recognition of other family members, neighborhood) through, for example, leisure times, promoting adjustments in their micro and macro interpersonal relationships (Mosquera \& 
Stobäus, 2008).

Mendes, Miranda, \& Borges (2010) remind us that:

It is important that there are strategies within these services with the caregiver as subject, resulting in recognition of the network as the basis of the process of caring for the quality of life of the disabled elderly and of the caregiver, who may negligent their own health. Many caregivers recognize that, once they take on this role, they no longer have time to take care of themselves, to have fun, that they are always tired. These process of home care interferes directly in the caregiver's social life.

2) Cognitive Development Program to improve memory, detecting personal characteristics of the elderly, motivational level and context in which they live (Marta)

The ability to encode the information retrieval process is a very important feature throughout life. This ability declines over the years, more precisely from the age of 60. In view of this, cognitive training is necessary for the maintenance of memory retrieval capacity.

The objective of the course would be to equip seniors with memory training, applying techniques that can be used in their daily life, taking into account their particularities, in the case of slight difficulties in memorizing basic daily tasks, adapted to the context in which they live.

It could be developed in consecutive stages, initially an expositive class (on the importance of the maintenance of the capacity of memorization, taking into account some daily tasks); followed by practical examples (such as using reminder cards to stick on the refrigerator door, post it notes to place into the schedule); specific exercises to improve memory fixation and mid- and short-term memory recovery tests; late memory recall exercises; followed by continuous partial evaluations (in the day, in a week, in two weeks, ...). It can be done in offices, for example, or classes, or material given in manuals.

Zimmer, Trombetta, Biduski, De Marchi, \& Colussi (2013) developed a mobile application for memory training in the elderly, which is used like a game and can improve memory in the elderly.

3) Differentiation between attention/memory difficulties and cognitive loss (Neusa)

As the elderly population increases, neurodegenerative diseases are also more frequently diagnosed. Thus, one can think of courses of short duration to help the elderly to have a better quality of life, with greater quality of memory.

A course with a few elderly participants would have an introduction, to review with them concepts and functioning of memory, showing the difference between attention difficulties, memory difficulties and real cognitive loss. It would follow with application of neuropsychological tests, demonstrating problems of attention, memory and cognitive loss. Then strategies would be developed to show how to deal with these difficulties, through work with texts and interpretation, lists of purchases, among others, with the purpose of learning to focus attention 
and consequently improve memory.

A post-implementation reappraisal of strategies could be done to see what differences are detected, as well as a re-evaluation at three and six months.

As proposed Takechi et al. (2017), it is important to prevent memory and cognitive loss with more intervention with social capital, because in research the "[...] result indicates the existence of a significant correlation between social capital and cognitive functions of the elderly living in a local community", more so in Alzheimer's Syndrome.

4) Skin care for the elderly (Campos)

With the growth of the Brazilian elderly population, which is occurring at an unprecedented level, one of the great challenges to be faced in the coming decades is skin care, which is worthy of note as it can create an improvement in the quality of life of this portion of the population.

A workshop could be carried out, through the use of printed and audiovisual materials, with a theoretical part, showing texts and images concerning the physiological changes that occur in the skin of the elderly and skin changes that develop over time, linked to two components, intrinsic and photoaging, to recognize differences and help prevent them. Intrinsic aging is further reflected by clinical changes seen over time in sun-protected skin, photoaging further denotes skin changes attributable to chronic exposure to the sun. With the knowledge acquired, the students will have a good level of satisfaction and the possibility of applying and multiplying this knowledge in real life.

Also, rapid tests could be performed on some findings in the skin of some of these elderly people.

Freitas \& Waldman (2011) note that”, “[...] results allowed us to consider that the physiological alterations of the skin of the elderly should be observed in the formulation of nursing diagnoses and interventions and that the nursing process should be used as a tool in the evaluation of the elderly's health, since it allows for the adequate planning of care", not only for nurses, but for all caregivers in Biomedical Gerontology.

Piccioni et al. (2017) observed that "specific combinations of active ingredients was clinically effective and safe, and contributed to skin surface hydrolipidic film regeneration, improvement of wrinkle depth and reduction of redness", as good skin care.

5) Oral Health and Cooking Techniques for the Elderly (Vanessa)

Accompanying the 'pandemic' that the world is experiencing an increase in the life expectancy of the population, is an increasingly clear knowledge of what is required of the health conditions facing the diverse needs of a functional aging population.

A developed discipline can have this contents: 1) to know the oral health conditions of the elderly; 2) introduce knowledge of basic cooking techniques with the aim of improving the elderly's diet; and 3) promote the quality of life of the elderly. Content on oral health of the elderly would be developed; Digestive 
process where it begins and where it ends; Mastication, importance of caring for teeth and prostheses; and Cooking techniques that facilitate the digestive process.

Theoretical classes (introduction of concepts of oral health, with use of play material to illustrate the components of the mouth, chewing and swallowing) would be carried out; with dolls to (re) see the processes of digestion of the human being, from tasting/olfaction, to mastication/deglutition, degradation and elimination of residues; on the importance of oral hygiene to maintain proper health and chewing capacity; concepts of healthy eating for the elderly, with different properties and consistencies of food; execution of basic cooking techniques that improve the food according to chewing capacity, and the different possibilities of food preparation with the use of appropriate cooking techniques.

Sato et al. (2018) says that there is a strong relationship between Quality of Life, Quality of Sleep and Oral Health Conditions in Japan's elderly population, as observed in other studies, and "people with low oral health-related QOL exhibit poor sleep quality". We can also observe the relation between low oral care and infections/immunity alterations, leading to a poor quality of life.

6) Difficulties related to the feeding of the elderly (Larissa)

It is known that patients between 65 - 70 years of age who exhibit weight loss and difficulties related to an adequate diet, combine with problems in relation to the quality of life and a decreased immunity, causing infectious diseases and other health problems.

Often these elderly people do not know how to relate elements of their food with the use of food, in terms of quantity and quality, and more effective chewing and swallowing.

Thus, the idea of presenting a workshop, with a team from the Local Health Center, with a speech and hearing specialist in dysphagia and gerontology, to assist in prevention and help guide the elderly. Also aiding in assessing the adaptation of dental prostheses or referral to the dentist, depending on the necessity of care. And help carry out guidelines regarding the proprioception of food in the oral and pharyngeal cavity, in order to be able to identify the difficulties more clearly.

These would be activities with resources showing data explaining how the swallowing process occurs, from the beginning of swallowing (oral phase, pharyngeal and esophageal phase); alerts for food related symptoms (coughing, choking, respiratory changes), alerting to the importance of a well-adapted prosthesis and/or well cared for teeth. A second part would be food for testing and actual oral use during the workshop (water, yogurt and crackers water and salt, among others).

Magalhães et al. (2011), in his work in two workshops with a group of elderly people, discussing alternatives that would enable healthy food intake and demystification of some myths related to dietary practices, concluded that "it is possible to perceive the group's understanding of the importance of valuing simple 
habits, but that contribute to the quality of life".

\section{Final Considerations}

From what we have shown in this paper, it can be concluded that the increase of an aging population has been accompanied by an increase in life expectancy. Along with aging, illnesses and other causes of malaise also accompany in the same proportion, if not in greater proportion. Aging is sometimes linked to an impairment or impairment of certain abilities, which can be a source of discomfort, ill-health and the onset of other illnesses in individuals after a certain age.

Through studies involving Positive Psychology, effective results have appeared regarding the promotion of well-being. In this sense, based on our study, we understand that the theoretical support of Positive Psychology emphasizes the recognition of potentialities and strengths of the people themselves, highlighting their positive traits, which may help lift them out of possible, less positive situations.

Thus, we believe that an intersectoral action that combines Positive Psychology, Health Psychology and Health Education, in research and interventions, especially in this age group, can bring satisfactory results in favor of happiness and well-being, being able to evidence improvements in disease prevention and health promotion throughout human aging, increasing overall health with a view to possible longevity.

\section{Conflicts of Interest}

The authors declare no conflicts of interest regarding the publication of this paper.

\section{References}

Barba, P. C., De, S. D., Martinez, C. M. S., \& Carrasco, B. G. (2003). Promoção da Saúde e Educação Infantil: Caminhos para o desenvolvimento [Health Promotion and Early Childhood Education: Pathways to Development]. Paidéia, 13, 141-146.

http://www.scielo.br/pdf/paideia/v13n26/02.pdf https://doi.org/10.1590/S0103-863X2003000300002

Brasil (1988). Constituição da República Federativa do Brasil [Constitution of the Federative Republic of Brazil]. Brasília: Senado Federal.

Brasil, Ministério da Saúde. (2016). Dados DATASUS [DATASUS Data] [Internet]. Brasília: Ministério da Saúde. http://tabnet.datasus.gov.br/cgi/tabcgi.exe?ibge/cnv/popuf.def

Cardoso, C. (2014). Expectativa de vida dos brasileiros sobre para 74,9 anos, diz IBGE [Life Expectancy of Brazilians over 74.9 Years, Says IBGE]. Ciência e Saúde. http://g1.globo.com/ciencia-e-saude/noticia/2014/12/expectativa-de-vida-dos-brasileir os-sobe-para-749-anos-diz-ibge.html

De Freitas, L. D. O., \& Waldman, B. F. (2011). Processo de envelhecimento da pele do idoso: Diagnósticos e intervenções de enfermagem [Elderly Skin Aging Process: Nursing Diagnoses and Interventions]. Porto Alegre: Estudos Interdisciplinares sobre o Envelhecimento, v. 16, edição especial, 485-497.

http://www.seer.ufrgs.br/RevEnvelhecer/article/view/17924 
Delors, J. (2005). A educação para o século XXI: Questões e perspectivas [Education for the 21st Century: Issues and Perspectives]. Porto Alegre: Artmed.

Gomes, M. A., Timm, J. W., Stobäus, C. D., \& Mosquera, J. J. M. (2014). Contribuições da Psicologia Positiva nas intervenções psicopedagógicas [Contributions of Positive Psychology in Psychopedagogical Interventions]. In Anais Simpósio Latino Brasileiro de Psicologia Positiva (pp. 35-38). Foz do Iguaçu-PR/Rio de Janeiro-RJ.

Hué, C. (2008). Bienestar docente y pensamiento emocional [Teacher Well-Being and Emotional Thinking]. Madrid-ES: Wolters Kluwer España.

IBGE. (2003). IBGE lança estatísticas do século XX [IBGE Launches 20th Century Statistics]. 2003.

http://www.ibge.gov.br/home/presidencia/noticias/29092003estatisticasecxxhtml.shtm

Júlio, C. A. (2009). Reinventando você: A dinâmica dos profissionais e a nova organização [Reinventing You: The Dynamics of the Professionals and the New Organization]. Edição Compacta. Rio de Janeiro: Elsevier.

Kummer, S. S. (2014). Análise comparativa dos custos de internações hospitalares de idosos, pelo SUS, em municípios com diferentes realidades de renda média domiciliar per capita [ Comparative Analysis of the Costs of Hospital Admissions of the Elderly, by SUS, in Municipalities with Different Realities of Average Household Income Per Capita]. Porto Alegre: Dissertação (Mestrado em Gerontologia Biomédica)-Pontifícia Universidade Católica do Rio Grande do Sul. http://tede2.pucrs.br/tede2/handle/tede/2719

Lebrão, M. L. (2007). Aging in Brazil: Demographic and Epidemiological Transition Aspects. Saúde Coletiva, 4, 135-140.

Magalhães, F. C. et al. (2011). Healthy Eating: A Strategy for the Quality of Life of the Elderly (pp. 1-4). XV Encontro Latino Americano de Iniciação Científica e XI Encontro Latino Americano de Pós-Graduação, Anais... Universidade do Vale do Paraíba.

http://www.inicepg.univap.br/cd/INIC_2011/anais/arquivos/RE_0530_0625_01.pdf

Mendes, G. D., Miranda, S. M., \& Borges, M. M. M. de C. (2010). Caregiver Health of the Elderly: A Challenge for Caregiving. Revista Enfermagem Integrada, 3. https://www.unilestemg.br/enfermagemintegrada/artigo/v3/04-saude-cuidador-idososdesafio.pdf

Mosquera, J. J. M., \& Stobäus, C. D. (1983). Health Education: A Challenge for Changing Societies (2nd ed.). Porto Alegre: Ed. Universidade/UFRGS.

Mosquera, J. J. M., \& Stobäus, C. D. (2006a). Self-Image, Self-Esteem and Self-Realization: Quality of Life in University. Psicologia, Saúde \& Doenças, 7, 83-88.

Mosquera, J. J. M., \& Stobäus, C. D. (2006b). Vida Adulta: Superdotação e motivação. Revista Educação Especial, No. 28.

http://periodicos.ufsm.br/educacaoespecial/article/view/4292/3226

Mosquera, J. J. M., \& Stobäus, C. D. (2008). The Teacher, Healthy Personality and Interpersonal Relationships: For an Education for Affectivity. In D. Enricone (Ed.), Being a Teacher (6th ed., pp. 67-78). Porto Alegre: EdiPUCRS.

Mosquera, J. J. M., Stobäus, C. D., \& Timm, E. Z. (2009). The Teacher and Self-Care: Looking at Life Itself as a Work of Art. Why Not? Ciência em Movimento, 22, 47-53. https://www.metodista.br/revistas/revistas-ipa/index.php/EDH/article/viewFile/115/80

Nações Unidas Do Brasil-ONU/BR (2014). World Will Have 2 Billion Elderly People by 2050; WHO Says "Aging Well Must Be Global Priority".

https://nacoesunidas.org/mundo-tera-2-bilhoes-de-idosos-em-2050-oms-diz-que-envel 
hecer-bem-deve-ser-prioridade-global/

Néri, A. L. (2013). Concepts and Theories about Aging. In L. Malloy-Diniz, D. Fuentes, \& R. M. Cosenza (Eds.), Neuropsychology of Aging: A Multidimensional Approach (pp. 17-42). Porto Alegre: Artmed. http://www.larpsi.com.br/media/mconnect_uploadfiles/c/a/cap_016.pdf

Pacico, J. C., \& Bastianello, M. R. (2014). The Origins of Positive Psychology and the First Brazilian Studies. In C. S. Hutz (Ed.), Evaluation in Positive Psychology (pp. 13-21). Porto Alegre: Artmed.

Piccioni, A. et al. (2017). Improving Skin Aging, Skin Hydration and Sensitive Skin with Four Specific Skin Care Products: Results from a Single-Centre, Observational, Prospective Study. Journal of Cosmetics, Dermatological Sciences and Applications, 7, 48-56. https://doi.org/10.4236/jcdsa.2017.71005

Pinto, R. B. R., \& Bastos, L. C. (2007). Approach of Research in Epidemiology Applied to Gerontology in Brazil: A Review of the Literature in Periodicals, between 1995 and 2005. Revista Brasileira de Epidemiologia, 10, 361-369. https://doi.org/10.1590/S1415-790X2007000300007

Portella, M. (2014). The Science of Good Living: Proposals and Techniques of Positive Psychology (2nd ed.). Rio de Janeiro: CPFA-RJ.

Rossi, A. M. (1997). 101 Ways to Live Better. Porto Alegre: Artes e Ofícios.

Santos, M. F. O., Moreira, M. S., Rocha, S. G., \& Ribeiro, V. F. (2011). Intersectoriality as a Way to Overcome Challenges in Health Education. Revista Brasileira de Medicina de Família e Comunidade, 6, 288-292.

Sato, M. et al. (2018). Relationship among Health Related Quality of Life, Quality of Sleep, and Oral Health Condition. Health, 10, 204-214. https://doi.org/10.4236/health.2018.102017

Savater, F. (1998). The Value of Educating (2nd ed.). São Paulo: Planeta.

Seligman, M. (2009). Authentic Happiness: Using the New Positive Psychology for Permanent Achievement. Rio de Janeiro: Objetiva.

Seligman, M. (2011). Flourish: A New Understanding of the Nature of Happiness and Well-Being. Rio de Janeiro: Objetiva.

Snyder, C. R., \& Lopez, S. J. (2009). Positive Psichology. São Paulo: Artmed.

Takechi, S. et al. (2017). Relationship between Social Capital and Cognitive Functions among Community-Based Elderly. Advances in Alzheimer's Disease, 6, 45-51. https://doi.org/10.4236/aad.2017.62004

Timm, E. Z., Mosquera, J. J. M., \& Stobäus, C. D. (2009). Resilience: Necessity and Possibility of Problematization in Teaching Contexts. Educação, Porto Alegre, 31, 39-45. http://revistaseletronicas.pucrs.br/ojs/index.php/faced/article/viewFile/2755/2103

Timm, J. W., Gomes, M. A., Stobäus, C. D., \& Mosquera, J. J. M. (2014). Applications of Positive Psychology to Education: In Search of Teacher Well-Being. In Anais et al. (Eds.), Simpósio Latino Brasileiro de Psicologia Positiva (pp. 27-33). Foz do Iguaçu-PR/Rio de Janeiro: Psicologia Positiva.

Timm, J. W., Stobäus, C. D., \& Mosquera, J. J. M. (2014). Positive Psychology and Teacher Welfare: State of Knowledge CAPES, 2011-2012. Educação Por Escrito, 5, 228-239. https://doi.org/10.15448/2179-8435.2014.2.17805

UNIMED/POA (2009). Search Index of Well-Being (IBE). http://projetobemestar.unimedpoa.saude.ws/cliente/category/ibe/

Veras, R. P. (1991). Brazil Is Getting Older: Demographic Changes and Epidemiological 
Challenges. Revista de Saúde Pública, 25, 476-488.

https://doi.org/10.1590/S0034-89101991000600010

WHO Organização Mundial Da Saúde OMS (1946). Constitution. New York, NY: OMS.

Wright, J. T. (2008). Health in Brazil and Latin America. São Paulo: Fundação Instituto de Administração (FIA).

Zimmer, M., Trombetta, M., Biduski, D., De Marchi, A. C. B., \& Colussi, E. L. (2013). A Mobile Application for Memory Training in the Elderly: Development and Evaluation. New Ideas in Educational Informatics TISE 2013.

http://www.tise.cl/volumen9/TISE2013/715-718.pdf 